\title{
Punch Planting to Establish Grass
}

\author{
VICTOR L. HAUSER
}

\begin{abstract}
Perennial grasses are difficult to establish from seed in the Southern Great Plains. The conventional planting practice is to plant grass seeds 1 to $2 \mathrm{~cm}$ deep in the soil; but that soil layer often dries quickly, thus preventing plant establishment. I investigated punch planting, which may avoid the problem of soil drying around grass seeds. Punch planting is defined as the placement of seeds in open, small-diameter holes, punched in the soil to a much greater depth than conventional planting. Under drying conditions, punch planting produced satisfactory stands for $\mathbf{5}$ grasses, but conventional planting produced failures. Where the soil was kept wet, both methods produced satisfactory grass stands. Optimum depth of punch planting was related to seed size and seedling vigor. Small-diameter holes $(0.6 \mathrm{~cm})$ produced best plant emergence, because soil at the bottom of the se holes dried slower than at the bottom of large holes. Punch planting may offer a solution to the problem of seeding failures.
\end{abstract}

Native grasses, legumes, and other forage plants are often difficult to establish in both pasture and range conditions. Seeding failures are costly because seedbed preparation, secd, and sceding costs are lost, and production is lost from the land for one or more years.

A 3-year study of grass seeding in the Great Plains (Great Plains Council 1966) showed that seeding failures were most common in the Southern Great Plains, and that more than $50 \%$ failures occurred even in humid areas. Weather conditions often determined the degree of success or failure, and fallowed seedbeds or planting in crop stubble improved the chances for successful establishment. However, even the best treatments produced numerous failures.

Germination and establishment of grasses or legumes require that several factors or conditions be within some adequate range in the seed zone. Soil and air temperatures and soil water content are among the most critical conditions. Temperature can be controlled partially by selecting planting date wisely. However, soil water is often a serious limiting factor in the Southern Plains because the top $2 \mathrm{~cm}$ of soil, where grass seeds are planted, dries very quickly.

Dowling and Smith (1976) reported that plant establishment for two Australian pasture grasses and two legumes was linearly related to available soil water during the first 6 weeks after sowing seeds on the soil surface. Army and Hudspeth (1960) found that, in summer on the Texas High Plains, the top $1.3 \mathrm{~cm}$ of Pullman silty clay loam soil dried from field capacity to wilting point within 1 day. Wiegand (1962) showed that during summer the top $2 \mathrm{~cm}$ of a sandy clay loam dried from field capacity to wilting point within 2 days in the Lower Rio Grande valley of Texas. Reginato (1975) reported that the top $1 \mathrm{~cm}$ of a loam soils at Phoenix, Arizona, dried from near field capacity to the wilting point within 4 hours in

Author is agricult ural engineer U.S. Dep. Agr.. Agr. Res. Serv., Tex., P.O. Box 748, Temple, TX 76501

This report is a contribution from the U.S. Dep. Agr.. Agr. Res. Serv., in cooperation with Texas Agricultural Experiment Station. Texas A\&M University.

Mr. Norman D. Erskine, engineering research technician, collected and summari/ed much of the data in this paper. His high quality work is gratefully recognized.

Manuscript received September 15, 1980. winter. The seeding zone for grasses (upper $2 \mathrm{~cm}$ of soil) can often dry to wilting point in 1 day in the Southern Plains; however, grass seeds require several days in moist soil to germinate and produce seedlings with roots long enough to reach moist soil below the $2-\mathrm{cm}$ depth.

Cary (1967) demonst rated that lettuce and carrots could be more easily established by punch planting than by conventional methods. In punch planting, the seeds are placed in the bottom of an open hole that is deeper than normal planting depth (Fig. 1). The soil at the punch planting depth remains wet much longer than that at the conventional planting depth. Cary and Heinemann (1977), Heinemann et al. (1973), and Wilkins et al. (1979), who invented and tested punch planting machines, showed that punch planting was better than conventional planting for some vegetable crops.

I studied punch planting to determine if it is a better way to establish numerous, healthy grass plants.

\section{Methods}

The studies reported here were conducted in the greenhouse. Field studies were also completed but the data are not reported in this paper because they are for 1 year only. The soil used in the greenhouse was Crockett sandy loam from Falls County, Texas (Wyrick 1978). Six boxes, which were $63.5 \mathrm{~cm}$ square and $91 \mathrm{~cm}$ deep, were filled with air-dried, sieved soil and placed in an airconditioned greenhouse. A 5-cm-thick sand filter was placed in the bottom of each box to permit drainage. After initial wetting, tensiometers were inserted in each box at the 15- and 30-cm depth. Free water evaporation was measured daily from tubular brass containers $6.35 \mathrm{~cm}$ in diameter and $17.1 \mathrm{~cm}$ deep, which were buried with $2.5 \mathrm{~cm}$ protruding above the soil in 2 boxes. The water level in the brass tubes, was maintained near the level of the soil

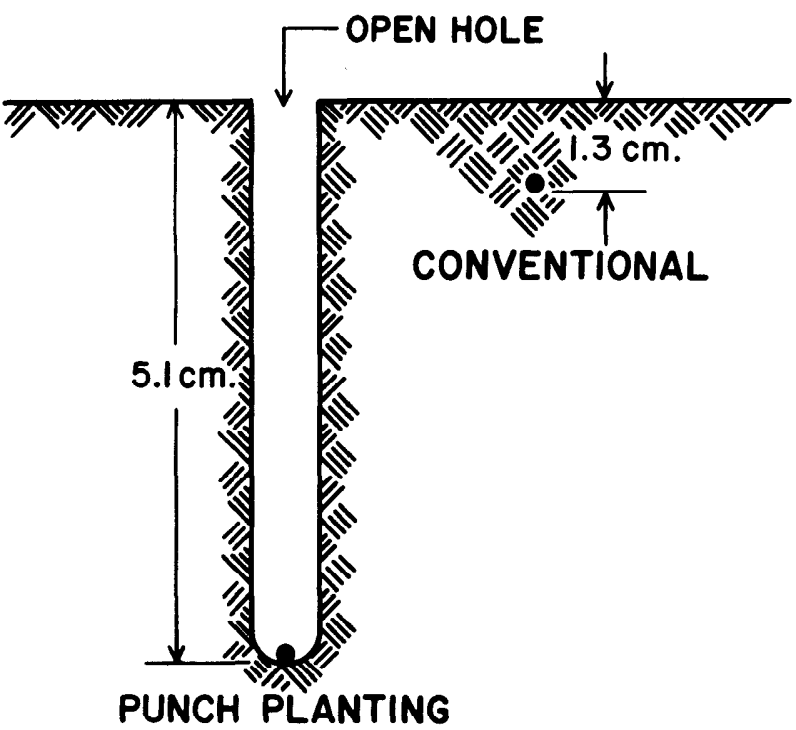

Fig. 1. Schematic diagram of punch planting vs. conventional planting. 
surface. Soil temperatures were measured by thermocouples, air temperature and humidity were measured by a standard hygrothermograph; and soil water was measured gravimetrically at seeding and test termination, and daily by the tensiometers.

The holes for punch planting were made with bullet-nosed steel rods of the appropriate diameter, that were inserted into the soil through a template. Conventionally planted seeds were placed in furrows of appropriate depth, quickly covered with moist soil, and compacted to simulate field planting. Punch-planting depth was a variable under study.

The grasses planted were: 1. weeping lovegrass (Eragrostis curvula); 2. kleingrass (Panicum coloratum); 3. TAM wintergreen hardinggrass (Phalaris aquatica); 4. Kentucky 31 tall fescue (Festuca arundinacea); and 5. eastern gamagrass (Tripsacum dactyloides). The average number of seed per gram for each grass is as follows: lovegrass, 3300; kleingrass, 1000; hardinggrass, 750; fescue, 450; and gamagrass, 16.

It is possible that punch planting might be successful for one or two species and not for others. Therefore, this set of grasses was chosen for these experiments because it contains a large range in seed size and difficulty of establishment, and both warm- and cool-season grasses. Lovegrass seeds are very small but they are rela tively easy to establish. Kleingrass is difficult to establish (Wester and Dahl 1977). Eastern gamagrass has very large seed, can be planted up to $5 \mathrm{~cm}$ deep, and those few seeds that germinate produce very robust seedlings. The two cool-season grasses differ greatly in ease of establishment: fescue is easily established but hardinggrass is difficult to establish in the field.

The germination rate was highly variable between seed lots and species; therefore, germination tests of each seed lot were run as specified by the Association of Official Seed Analysts (1970). The number of seeds planted per treatment row was adjusted according to the germination rate of the seed being used. The germination rate varied as follows: lovegrass, 94 and 95\%; kleingrass, 57, 74, and $87 \%$; hardinggrass, 42 and $68 \%$; fescue, $87 \%$; and gamagrass, $50 \%$. Either 10,20 , or 30 seeds $(1,2$, or 3 seeds per punched hole) were planted per row to give 9 or more live seeds per row. Captan was applied to the seeds to control seedling diseases on all treatments.

The greenhouse environment was kept dry to simulate the field environment for grass seeds and seedlings. Sometimes, as noted in the results section, water was added to all boxes after planting to simulate natural showers or to avert complete failure for the test. Water evaporation rates ranged between 0.6 and $1.3 \mathrm{~cm}$ per day, and air and soil temperatures were maintained within the optimum range for each grass under test in the greenhouse.

I conducted six tests that included several variables in addition to conventional and punch planting, the primary variables. The hole diameter may affect the drying rate of the hole bottom and thus affect germination. The hole depth may also affect the drying rate of the hole bottom but the food reserves and seedling vigor of a particular grass is a limiting variable. Surface mulches are commonly accepted as beneficial to seedling establishment and may affect the success of punch planting. Seed size and seedling vigor may permit some seeds to be planted deep enough by conventional methods to negate any benefits due to punch planting. Therefore, I tested all of these variables.

In test la I compared conventional and punch planting methods with ample water provided after planting for lovegrass and kleingrass (warm-season grasses) and for hardinggrass (cool-season grass). In test lb I compared conventional and punch planting methods for lovegrass and kleingrass under dry conditions. All punch-plant holes were small $(0.6 \mathrm{~cm}$ dia. $)$ and 4 times the conventional planting depth.

In test 2 I evaluated the effect of hole diameter and included conventional planting as a check treatment. Lovegrass was chosen as the test grass because it is an easily established warm-season grass. Water was added to the soil surface on day 11 to avert severe drought damage. In two treatments, the seeds were covered with
$1.3 \mathrm{~cm}$ of dry or wet vermiculite in large diameter holes to conserve water around the seed.

In test 3 I compared conventional and punch planting methods for both bare soil and mulch cover. The mulch was bermudagrass hay cut 10 to $15 \mathrm{~cm}$ long, that was applied at $2500 \mathrm{~kg} / \mathrm{ha}$ to the surface of three boxes. I chose fescue for this test because it is a cool-season grass that is normally easy to establish in the field. Since the soil at the bottom of the punch hole was compacted by the punch, the hole in one treatment of this test was made by coring, to eliminate compaction.

In test $4 \mathrm{I}$ evaluated the effect of hole depth on germination and growth of kleingrass. The greenhouse climate was dry and no water was applied after planting.

In test 5 I evaluated the interaction of grass species (lovegrass and kleingrass) with hole depth. Lovegrass seeds are very small but they produce fast-growing seedlings. Although kleingrass seed sare much larger, they produce less vigorous seedlings.

In test 6 I compared conventional and punch planting methods for gamagrass and evaluated the effect of hole depth on emergence of plants produced by these very large seeds. Because the germination percentage of gamagrass seeds is low, I planted both ungerminated and germinated seeds. The germinated seeds had radicles that were less than $2 \mathrm{~mm}$ long when they were planted.

The experiments were ended when seedling emergence stopped. The results were expressed as percent emergence of the live seed planted, as determined by the standard germination test. The differences between means were tested by standard analysis of variance and Duncan's multiple range test ( $5 \%$ level), as described by Little and Hills (1972). The arcsine transformation did not affect the outcome of the statistical analysis.

\section{Results}

In the greenhouse tests, the surface soil dried rapidly like the drying of field soil reported in the literature. The data shown in Figure 2 are typical of measured soil-water content in the greenhouse tests and resemble measured soil-water distribution in the field. The soil at both the 15 - and the $30-\mathrm{cm}$ depths was wetter than field capacity during all tests except one, when suction at the $30-\mathrm{cm}$ depth only was 0.7 atmospheres.

The effects of surface soil-water supply on the effectiveness of punch planting is shown in Table 1 . When the soil surface was kept wet after planting, emergence was similar for each planting method and species; however, under dry conditions lovegrass emergence was markedly better for punch planting. Even though hardinggrass is often difficult to establish in the field, it produced excellent

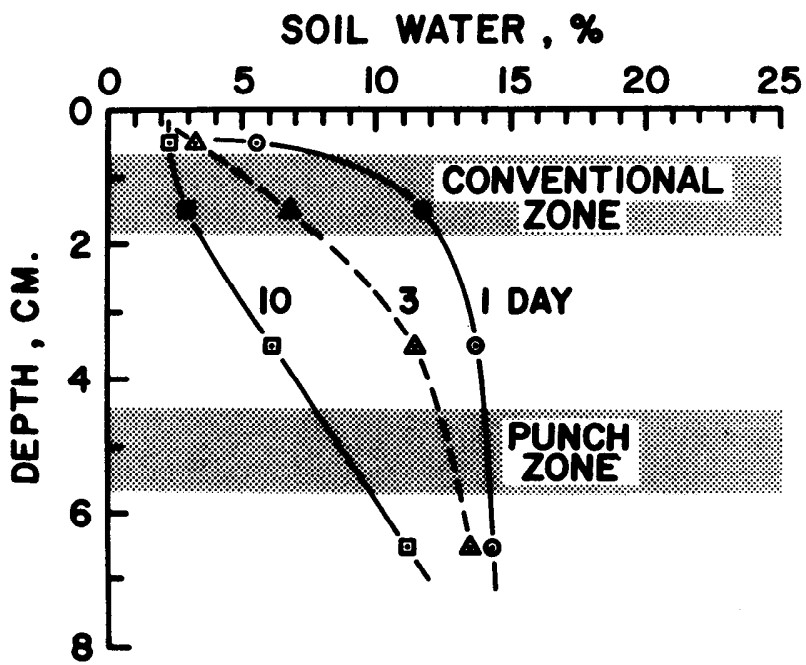

Fig. 2. Typical soil water distribution (\% by wt.) in the surface layers of greenhouse soil 1,3 , and 10 days after irrigation, in relation to the conventional or punch planting soil zones $10.5 \mathrm{~cm}$ water added after sampling on day 3. 
Table 1. Comparison of conventional and punch planting treatments in 0.6-cm diameter holes, under either wet or dry conditions, test $1 \mathrm{a}$ and $1 \mathrm{~b}$.

\begin{tabular}{lcc}
\hline \hline & \multicolumn{2}{c}{ Emerged $^{1}$} \\
\cline { 2 - 3 } Treatment & $\begin{array}{c}\text { Wet test } \\
(\%)\end{array}$ & $\begin{array}{c}\text { Dry test } \\
(\%)\end{array}$ \\
\hline Lovegrass & & \\
$\quad$ Conventional, $0.6 \mathrm{~cm}$ deep & $52 \mathrm{c}^{4}$ & $4 \mathrm{~b}$ \\
$\quad$ Punch $2.5 \mathrm{~cm}$ deep & $63 \mathrm{cb}$ & $33 \mathrm{a}$ \\
Kleingrass & & \\
$\quad$ Conventional, $1.3 \mathrm{~cm}$ deep & $48 \mathrm{c}$ & $0 \mathrm{~b}$ \\
$\quad$ Punch $5.1 \mathrm{~cm}$ deep & $42 \mathrm{c}$ & $11 \mathrm{~b}$ \\
Hardinggrass & & \\
$\quad$ Conventional, $1.3 \mathrm{~cm}$ deep & $90 \mathrm{ab}$ & - \\
$\quad$ Punch $5.1 \mathrm{~cm}$ deep & $96 \mathrm{a}$ & - \\
\hline
\end{tabular}

'Plants emerged above ground as a percentage of live seed planted.

${ }^{2}$ Well watered for first 20 days.

${ }^{3}$ Emergence at 14 days after planting, no water added.

${ }^{4}$ Within each column values followed by the same letter do not differ significantly according to the Duncan multiple range test.

emergence in this wet test. Hardinggrass was not planted in the dry test to allow space for more replication of lovegrass and kleingrass. The dry test ( $1 \mathrm{~b}$ ) was terminated after 14 days, which later experiments showed was insufficient time for punch-planted kleingrass to fully emerge.

Punch-planting holes should be as small as possible to reduce drying; however, it is easier to plant seeds in larger holes. Under dry conditions, the bottom of a $0.6-\mathrm{cm}$ diameter hole dried slower and produced greater emergence than did the $2.5-\mathrm{cm}$ diameter holes (Table 2). Although lovegrass is relatively easy to establish, conventional planting did not produce a satisfactory stand of plants in this test. The wet vermiculite which covered the seeds in this test also produced satisfactory emergence.

Table 2. The effect of hole diameter and planting treatment on emergence and total live plants of lovegrass under dry conditions, evaluated 18 days after planting, $(0.6 \mathrm{~cm}$ of water added 11 days after planting), test 2 .

\begin{tabular}{lcc}
\hline \hline Treatment & $\begin{array}{c}\text { Emerged }^{1} \\
(\%)\end{array}$ & $\begin{array}{c}\text { Live plants }^{2} \\
(\%)\end{array}$ \\
\hline $\begin{array}{l}\text { Conventional, }(0.6 \mathrm{~cm} \text { deep }) \\
\text { Punch plant }(2.5 \mathrm{~cm} \text { deep })\end{array}$ & $1 \mathrm{c}^{3}$ & $1 \mathrm{~b}$ \\
$\begin{array}{l}0.6 \mathrm{~cm} \text { dia., open holc } \\
1.3 \mathrm{~cm} \text { dia., open hole }\end{array}$ & $30 \mathrm{a}$ & $47 \mathrm{a}$ \\
$2.5 \mathrm{~cm}$ dia., open hole & $25 \mathrm{ab}$ & $57 \mathrm{a}$ \\
$2.5 \mathrm{~cm}$ dia., $+1.3 \mathrm{~cm}$ dry & $0 \mathrm{c}$ & $1 \mathrm{~b}$ \\
$\quad$ vermiculite & $8 \mathrm{bc}$ & $38 \mathrm{a}$ \\
$\begin{array}{l}2.5 \mathrm{~cm} \text { dia., }+1.3 \mathrm{~cm} \text { wet } \\
\text { vermiculite }\end{array}$ & $22 \mathrm{ab}$ & $51 \mathrm{a}$ \\
\hline
\end{tabular}

'Sce foot note 1, Table I.

2Total live plants above or below ground surface as a percentage of live seed planted. 'See footnote 4, Table 1.

In test 3, mulching significantly improved emergence for the punch plant treatment, but, although fescue is relatively easy to establish in the field, conventionally planted fescue produced no plants. Seed planted in the small punch-plant holes produced significantly more plants than conventional planting with or without mulch. Plant emergence from the large diameter holes covered by mulch was satisfactory, but it was very poor without mulch. Forming the hole by coring, to reduce soil compaction in the bottom of the hole, did not improve emergence (Table 3).

The hole depth in punch planting is important. If the hole is too shallow, the seed zone will dry too quickly, but, if the hole is too deep, the energy stored in the seed will be exhausted before the plant reaches the surface. The maximum hole depth for kleingrass is $5 \mathrm{~cm}$ or less (Table 4 and 5). Fewer seeds germinated in the deep
Table 3. The interaction of mulch and punch planting treatment on the emergence of fescue, 22 days after planting $(0.6 \mathrm{~cm}$. water applied on day 8), test 3 .

\begin{tabular}{lcc}
\hline \hline & \multicolumn{2}{c}{ Emerged! } \\
\cline { 2 - 3 } Treatment & $\begin{array}{c}\text { Mulch } \\
(\%)\end{array}$ & $\begin{array}{c}\text { No mulch } \\
(\%)\end{array}$ \\
\hline Conventional, $1.3 \mathrm{~cm}$ deep & $0 \mathrm{c}^{2}$ & $0 \mathrm{c}$ \\
Punch plant $5.1 \mathrm{~cm}$ deep & $85 \mathrm{a}$ & $60 \mathrm{ab}$ \\
Punch plant, $0.6 \mathrm{~cm}$ dia. & $81 \mathrm{a}$ & $8 \mathrm{c}$ \\
Punch plant, $2.5 \mathrm{~cm}$ dia. & $77 \mathrm{a}$ & $29 \mathrm{bc}$ \\
Cored hole, $2.5 \mathrm{~cm}$ dia. & 61 & 24 \\
$\quad$ Mean $^{3}$ & & \\
\hline
\end{tabular}

'See foot note 1, Table 1.

${ }^{2}$ Values which are followed by the same letter do not differ significantly according to Duncan multiple range test.

${ }^{3}$ Mean values for mulch treatments are significantly different at the $5 \%$ level.

holes than in the shallow holes and most or all plants died in the deep holes (Table 4). I did not determine the cause of poor germination and plant death in the deep holes.

Table 4. The effect of punch-planting hole depth on emergence of kleingrass, 21 days after planting in $0.6-\mathrm{cm}$ diameter holes (no water applied after planting), test 4 .

\begin{tabular}{lccc}
\hline \hline $\begin{array}{c}\text { Hole depth } \\
\mathrm{cm}\end{array}$ & $\begin{array}{c}\text { Emerged } \\
(\%)\end{array}$ & $\begin{array}{c}\text { Live }^{2} \\
\text { plants } \\
(\%)\end{array}$ & $\begin{array}{c}\text { Live plus }^{3} \\
\text { dead plants } \\
(\%)\end{array}$ \\
\hline 2.5 & $49 \mathrm{a}^{4}$ & $49 \mathrm{a}$ & $51 \mathrm{ab}$ \\
5.1 & $26 \mathrm{~b}$ & $37 \mathrm{~b}$ & $59 \mathrm{a}$ \\
7.6 & $1 \mathrm{c}$ & $5 \mathrm{c}$ & $38 \mathrm{~b}$ \\
10.2 & $0 \mathrm{c}$ & $0 \mathrm{c}$ & $16 \mathrm{c}$ \\
\hline
\end{tabular}

'See foot note 1, Table 1 .

${ }^{2}$ See footnote 2 , Table 2 .

${ }^{3}$ Total live plus dead plants, either above or below ground surface, as a percentage of live seed planted.

${ }^{4}$ See foot note 4 , Table 1.

Lovegrass seeds produced more plants and they emerged faster than kleingrass (Table 5). Lovegrass plants emerged quickest and produced the most seedlings in the shallow $(1.3-\mathrm{cm})$ holes; however, under more arid conditions a $2.5-\mathrm{cm}$ planting depth might be better. Plant emergence stopped before day 25 in test 5 . The data in Table 5 demonstrate the difficulty of establishing kleingrass and agreed with the results of work by Wester and Dahl (1977).

Eastern gamagrass seeds are large but often less than $15 \%$ of the seeds germinate. The gamagrass sceds used in test 6 were individually selected by color, size, and density to yield a seed lot whose germination rate was $50 \%$. Gamagrass seeds that do germinate, grow vigorously and they can be planted deep where the soil is moist. As expected, gamagrass seeds that were germinated before planting produced significantly more plants and forage than did

Table 5. The interaction of hole depth and grass variety on emergence from 0.6-cm-diameter holes, 4,11 , and 25 days after planting kleingrass and lovegrass (no water applied after planting), test 5.

\begin{tabular}{lcccc}
\hline & & \multicolumn{3}{c}{ Emerged on': } \\
\cline { 3 - 5 } Grass & Hole depth & $\begin{array}{r}\text { day } 4 \\
(\%)\end{array}$ & $\begin{array}{c}\text { day } 11 \\
(\%)\end{array}$ & $\begin{array}{c}\text { day } 25 \\
(\%)\end{array}$ \\
\hline Kleingrass & 1.3 & $19 \mathrm{c}^{2}$ & $28 \mathrm{bc}$ & $28 \mathrm{~b}$ \\
& 2.5 & $16 \mathrm{c}$ & $40 \mathrm{~b}$ & $41 \mathrm{~b}$ \\
& 5.1 & $0 \mathrm{c}$ & $24 \mathrm{c}$ & $43 \mathrm{~b}$ \\
Lovegrass & 1.3 & $66 \mathrm{a}$ & $77 \mathrm{a}$ & $74 \mathrm{a}$ \\
& 2.5 & $30 \mathrm{~b}$ & $75 \mathrm{a}$ & $73 \mathrm{a}$ \\
& 5.1 & $0 \mathrm{c}$ & $3 \mathrm{~d}$ & $6 \mathrm{c}$ \\
\hline
\end{tabular}

'See footnote 1, Table 1 .

${ }^{2}$ See footnote 4 , Table 1 . 
Table 6. The effect of planting depth and pregermination on emergence of gamagrass 8 days after planting, and on oven-dry top growth harvested 19 days after planting (no water applied after planting), test 6 .

\begin{tabular}{lll}
\hline \hline $\begin{array}{c}\text { Treatment and planting depth } \\
(\mathrm{cm})\end{array}$ & $\begin{array}{c}\text { Emerged } \\
(\%)\end{array}$ & $\begin{array}{c}\text { Yield } \\
(\mathrm{g})\end{array}$ \\
\hline $\begin{array}{l}\text { Conventional planting } \\
\text { 5.1, ungerminated (dry) seed }\end{array}$ & $\begin{array}{l}12 \mathrm{~d}^{2} \\
75 \mathrm{~b}\end{array}$ & $0.13 \mathrm{e}$ \\
5.1, pregerminated & $0.34 \mathrm{c}$ \\
Punch planting (1.3 cm diameter & & \\
hole) & & \\
5.1, ungerminated (dry) seed & $26 \mathrm{c}$ & $0.23 \mathrm{~d}$ \\
5.1, pregerminated & $98 \mathrm{a}$ & $0.61 \mathrm{a}$ \\
10.2, pregerminated & $97 \mathrm{a}$ & $0.50 \mathrm{~b}$ \\
20.3 pregerminated & $35 \mathrm{c}$ & $0.10 \mathrm{e}$ \\
\hline
\end{tabular}

ISee foot note I, Table I.

${ }^{2}$ See footnote 4 . Table 1 .

dry seed under both conventional and punch-planting treatments (Table 6). Again, punch planting at depths up to $10 \mathrm{~cm}$ produced significantly more seedlings than did conventional planting. The large gamagrass seed successfully established vigorous plants from holes as deep as $10 \mathrm{~cm}$.

\section{Discussion and Conclusions}

Significantly more grass plants were established by punch planting than by conventional planting methods when water was limited. Both air and soil temperatures were adequate for good growth in these tests. The high, soil-water content in the seed zone of punch-planted seeds was probably responsible for the good performance of punch planting.

The best hole diameter was the smallest tested, $0.6 \mathrm{~cm}$. The best hole depth va ried with seed size $-1.3-2.5 \mathrm{~cm}$ for lovegrass, $2.5-5 \mathrm{~cm}$ for kleingrass, and $5-10 \mathrm{~cm}$ for eastern gamagrass.

One problem with punch planting is that plant crowns form in the open hole, below the soil surface. As a result, adventitious roots which normally originate at the crown do not grow until the crown fills the hole and/or rain occurs and fills the hole with soil. Punch planting was successful with vegetable crops that have tap roots (Cary 1967, Wilkins et al. 1979). Tap-rooted plants do not require adventitious roots, thus do not have the same problem as grasses when planted in open holes.
There are two major problems that limit the use of the punchplanting method for grass planting in the Southern Great Plains. First, the application of punch planting in the field is complicated by the possibility of rainfall filling the holes with soil before plant emergence. Second, the punch planting machines that have been developed are too slow and not strong enough to be practical on many grasslands (Cary and Heinemann 1977, Heineman et al. 1973, Wilkins et al. 1979).

The concept of punch planting does have much merit; it did establish significantly more plants than conventional planting procedures. It is one way to avoid the problem of rapid drying of the seed zone for grasses planted in the Southern Great Plains.

\section{Literature Cited}

Army, T.J., and Elmer B. Hudspeth, Jr. 1960. Alteration of the microclimate of the seed zone. Agron. J. 52:17-22.

Association of Official Seed Analysts. 1970. Rules for testing seeds, 1970. Proc. Ass. Official Seed Analysts 60:116 p.

Cary, J.W. 1967. Punch planting to establish lettuce and carrots under adverse conditions. Agron. J. 59:406-408.

Cary, John W., and William H. Heinemann. 1977. Magnetic seed delivery autodibble planter. U.S. Patent No. 4,061,094.

Dowling, P.M., and R.C.G.Smith. 1976. Use of a soil moisture model and risk analysis to predict the optimum time for the aerial sowing of pastures on the Northern Tablelands of New South Wales. Austr. J. Exp. Agr. and Animal Husb. 16:871-874.

Great Plains Council. 1966. A stand establishment survey of grass plantings in the Great Plains. Great Plains Council, Rep. No. 23. 60 p.

Heinemann, W.H., Jr., J.W. Cary, and A.E. Dilworth. 1973. Experimental machines for autodibble planting. Trans. ASAE 16:656-659.

Little, Thomas M., and F. Jackson Hills. 1972. Statistical methods in agricultural research. UCD Book Store, Univ. of California, Davis 95616. $242 \mathrm{p}$.

Reginato, R.J. 1975. Sampling soil-water distribution in the surface centimeter of a field soil. Soil Sci. 120:292-294.

Wester, David B., and B.E. Dahl. 1977. Water and temperature influences on germination of range scedings. In: Research Highlights Noxious Brush and Weed Control Range and Wild life Management, vol. 8) Texas Tech Univ., Lubbock.

Wiegand, Craig L. 1962. Drying patterns of a sandy clay loam in relation to optimal depths of seeding. Agron. J. 54:473-476.

Wilkins, D.E., P.A. Adrian, and W.J. Conley. 1979. Punch planting of vegetable seeds-A progress report. Trans of ASAE 22:746-749.

Wyrick, Jim C. 1978. Soil survey of Falls county, Texas. U.S. Dep. Agr. Soil Conserv. Service. 128 p.

\title{
THANK YOU, ELANCO!
}

Elanco Products Company, a Division of Eli Lilly and Company, has generously provided funds to the Society for Range Management for the purpose of reducing the backlog of manuscripts now awaiting publication in the Journal of Range Management.

Bob Gaylord, SRM member with ELANCO Products Co., was instrumental in obtaining the additional funding. Members are encouraged to write a letter of appreciation to:

\author{
R.A. Gaylord \\ ELANCO Products Company \\ 740 South Alabama St. \\ Indianapolis, Indiana 46285
}

